\title{
Assessing Green Policies for the Rehabilitation and Sustainable Restoration of Mine Sites in Cameroon: Case of the Mayo-Darlé Mine Site, Adamawa Region
}

\author{
Daniel Essapo $^{1 *}$
}

Marcel Ekedi ${ }^{2}$

\begin{abstract}
Mining is not without negative consequences for the environment. It is appropriate for each concerned state, particularly Cameroon, to adopt and implement mining laws and regulations to reduce environmental risks. The former Mayo-Darle mine site in the Adamawa region that has been abandoned for several decades is a striking example of the limitations and lapses of national environmental protection policies. Hence, this study outlines an inventory of features in the concerned mine site while analyzing green policies related to the mining sector in Cameroon. The study attempts to modelize the socio-economic and environmental impacts in the sustainable management of the Mayo-Darle mine site. The study proposes the prescription of a green network to encourage artisanal sustainable practices within mining fields. This "eco-sustainable" strategy shall be specific to mine site development. The implementation of measures outlined in the proposed policy shall considerably improve environmental conditions around the mine site. This involves the establishment of a rehabilitation plan and realistic restoration of the Mayo Darle site for good preservation of the environment.
\end{abstract}

Keywords: Green Policies, Rehabilitation, Sustainable Restoration, Mine Sites, Mayo-Darlé, Cameroon.

\footnotetext{
${ }^{1}$ Environmental Research Associate, National Institute of Cartography-Cameroon , ${ }^{2}$ Geologist, National Institute of Cartography / University of Yaounde I-Cameroon *Corresponding author email: essapodaniel@gmail.com;
}

Ghana Journal of Geography Vol. 12 (2), 2020 pages 125-146

https://dx.doi.org/10.4314/gjg.v12i2.6 


\section{Introduction}

According to Ucilia Wang (2015), mined materials support roughly 45\% of the world's economic activities - yet large-scale mining leaves social and environmental scars. In developing countries, mining comes second after agriculture and accounts for more than 20 million people working in artisanal and small-scale mining (ASM) against 3.7 million in the formal sector. Although its economic importance has been given credits, its environmental impacts turn to be one of the world's greatest challenges of the century. Indeed, mining generates large volumes of waste rock, tailings, acid mine drainage, airborne dust, and other contaminants, which are deposited on land and in the air and water (Widerlund et al., 2014). For these reasons, mining is the focus of increasingly stringent environmental regulations. By systematically examining environmental impacts and adopting measures to mitigate these impacts, it is possible to make mining less destructive by becoming more environmentally sustainable. Reducing water and energy consumption, minimizing land disturbance and waste production, preventing soil, water, and air pollution at mine sites are the most known and used measures so far. It is equally important to conduct successful mine closures, which implies restoring the site to its origin. This includes covering up mine entrances, replanting grass and trees, and testing surrounding water, soil, and air for contaminants (Somarin. A, 2014). These activities shall ensure the sustainable development of this sector.

The operationalization of sustainable development in the mineral resource management field has a paradoxical dimension. Indeed, reflections around the theme of sustainability of resources over space and time are becoming increasingly important. One can thus believe that the destiny of a mine is to be closed at the end of a more or less long period of extraction of its ore. This reflection is based on the question of whether: this unavoidable depletion of the resource is incompatible with sustainable development. (Villeneuve; Riffon et al; 2015). This questioning is as hot as the demand for mineral raw materials is rising all over the world at the same time as international consensus is increasingly militating for the universal application of the principles of sustainable development. Reconciling the expansion of the mining industry with the requirements of sustainable development is thus a major challenge and several shortcomings persist in the operationalization of the concept in the mining sector.

Since the early 1990s, Cameroon has developed a set of national environmental laws and policies to improve protection and govern its ecological and mining sectors. The Growth and Employment 
Assessing Green Policies for the Rehabilitation and Sustainable Restoration of Mine Sites in Cameroon: Case of the Mayo-Darlé Mine Site, Adamawa Region

Strategy Paper (GESP), which defines the development policy in Cameroon for the period 2010-2020, includes the mining sector among its favorite pillars for the achievement of its objectives. This document reveals that the State intends to work in such a way as to "promote and encourage research, exploitation, and transformation of mineral resources necessary for the economic and social development of the country". By the Strategic Environmental and Social Assessment (ESES) of the Cameroonian mining sector, carried out within the framework of the "Project for Capacity Building in the Mining Sector" (PRECASEM), Cameroon does not have a "mining sector policy letter". This constitutes a major handicap in particular for the steering of the sector, inter-ministerial consultation, and dialogue with civil society (ESES, 2015). However, without this tool, the state has attributed more than 300 mining exploration permits, including those of the uranium ore (EITI Report 2013). Of the 300 permits, allocated 125 of them were still valid in June 2014, showing how prominent and active the mining industry is developing in Cameroon.

These advanced green policies were established for the strategic development of aspects like biosafety, climate change adaptation, and land degradation. These were done as a response to national needs as well as to help Cameroon fulfill its obligations to International Environmental Conventions. An important example could be that of the African Convention on the Conservation of Nature and Natural Resources (known as Algiers Convention) which is a continent-wide agreement signed in 1968 in Algiers. It supersedes the Convention Relative to the Preservation of Fauna and Flora in their Natural State of 1933 and has been superseded by the African Convention on Conservation of Nature and Natural Resources (revised) signed in Maputo in 2003. This convention is applicable when considering pre and post-mining extraction activities. Furthermore, Small-scale mining in Cameroon has indeed played an important role in the development of the economy. It offers to the rural population a diversified number of basic economic activities, hence boosting employment in the mining exploitation as well as in the development of proximity services within the sector (NEMP, 2009). Nevertheless, could notice some insufficient information and knowledge with regards to human impacts on health, lifestyle, the specificity of socioeconomic groups, and cultural aspects on which more light has to be thrown (Mokam, Tsikam, et al; 2012). The management of the artisanal miners is in the mandate of the government through the Ministry of Mine and Industrial Development. There are around 200 artisanal mining cooperatives in Cameroon.

According to Ilboudo (2012), at the end of a mining life cycle and mines are decommissioned, there is the need to rehabilitate the site and that requires several actors who must work together to ensure 
proper rehabilitation of mines. Central questions that must be answered for any rehabilitation projects include who are these actors? What are their recommendations for rehabilitation? What roles do these actors play in the rehabilitation process and in what ways can inter-agency collaboration influence the success or otherwise of such rehabilitation efforts? The environmental rehabilitation of mine sites is viewed as part of a redevelopment strategy. Indeed, these issues need to be addressed to ensure the sustainable redevelopment of an area. Cleaning the mining sites is important for the local economy especially for declining mono-structured cities for which the heavy mineral industry was the major employer (Cobârzan, 2008). Mining activities contribute more than $80 \%$ of the degradation of the environment. There is therefore a need to rehabilitate mining sites during or at the end of the operation. According to OECD (2012), the wide dissemination of good practices following the logic of the global scope of sustainable development, good governance, and global innovative actions help in strengthening basic sustainable actions in emerging or developing countries' mining sector. Indeed, it marks the beginning of the establishment of a system that shall take into account sociopolitical and ecological solutions to confront the phenomenon of degradation of mining sites. The sustainable management of mine sites in pre or post-operation involves a lot of pragmatism and strategy development that would take into consideration organizational, planning, and societal aspects. Hence, our concern in this study is an attempt to show how a completed rehabilitation and sustainable restoration of a mine site as that of the Mayo Darlé mine site bequeath to the population a satisfactory environment that is compatible with future use. The challenge would be to set up a green policy conducive to the ecological, economic, and social development of this old mine in the locality of Mayo-Darlé. This article is divided into two main parts. The first do an inventory of the Mayo Darlé mine site while analyzing the environmental policies governing the sector at the national level. The second proposes the establishment of a green and sustainable policy specific to the management of the mining site after exploitation.

\section{Methodology}

\section{Presentation of the Study Area}

Mayo-Darlé is a community found in the Mayo-Banyo Division, Adamawa region in Cameroon. Its name originates from the main river "Mayo-Darlé" that crosses the town. This community is bordered on the north by Nyawa village, on the south by Mayo-Njinga on the east by Bambol, and on the west by the Mambilas Mountains. With a total surface area of $1920 \mathrm{~km} 2$ and a population of 7493 inhabitants in 2005, and has tripled to 23137 inhabitants presently (Mayo-Darlé Municipal 
Assessing Green Policies for the Rehabilitation and Sustainable Restoration of Mine Sites in Cameroon: Case of the Mayo-Darlé Mine Site, Adamawa Region

Development Plan, 2014), it is characterized by a Sudano-Guinean climate made of two seasons (dry and rainy). Concerning its orography, it is located on a plateau.

Socio-economically, the Mayo-Darlé sub-division has a much-diversified economy that ranges from a subsistence economy characterized by agro-pastoral activities to the developing economy relatively commercial. The activities most practiced by the populations are agriculture, livestock breeding, beekeeping, petty trading, handicrafts, and the artisanal exploitation of the Colombo-tantalite (Ta) that abounds in its subsoil. Its economic potential is also based on the diversity of its mineral resources such as tin ( $\mathrm{Tn}$ ) and some cobalt (Co). It also has several natural resources such as gallery forests, dense forest, cultivable land, tourist sites, lowlands, swamps, lakes, streams, and sand just to name a few (Mayo-Darlé Municipal Development Plan, 2014). Given its predisposition, our choice focused on this area as our case study due to its rich mineral constitution and its environmental as well as socio-cultural potentials. This research will have as the main challenge to make Mayo-Darlé a typical model of a sustainable pos-exploitation mine site in Cameroon. This shall be through the rehabilitation and restoration processes this study proposes. 


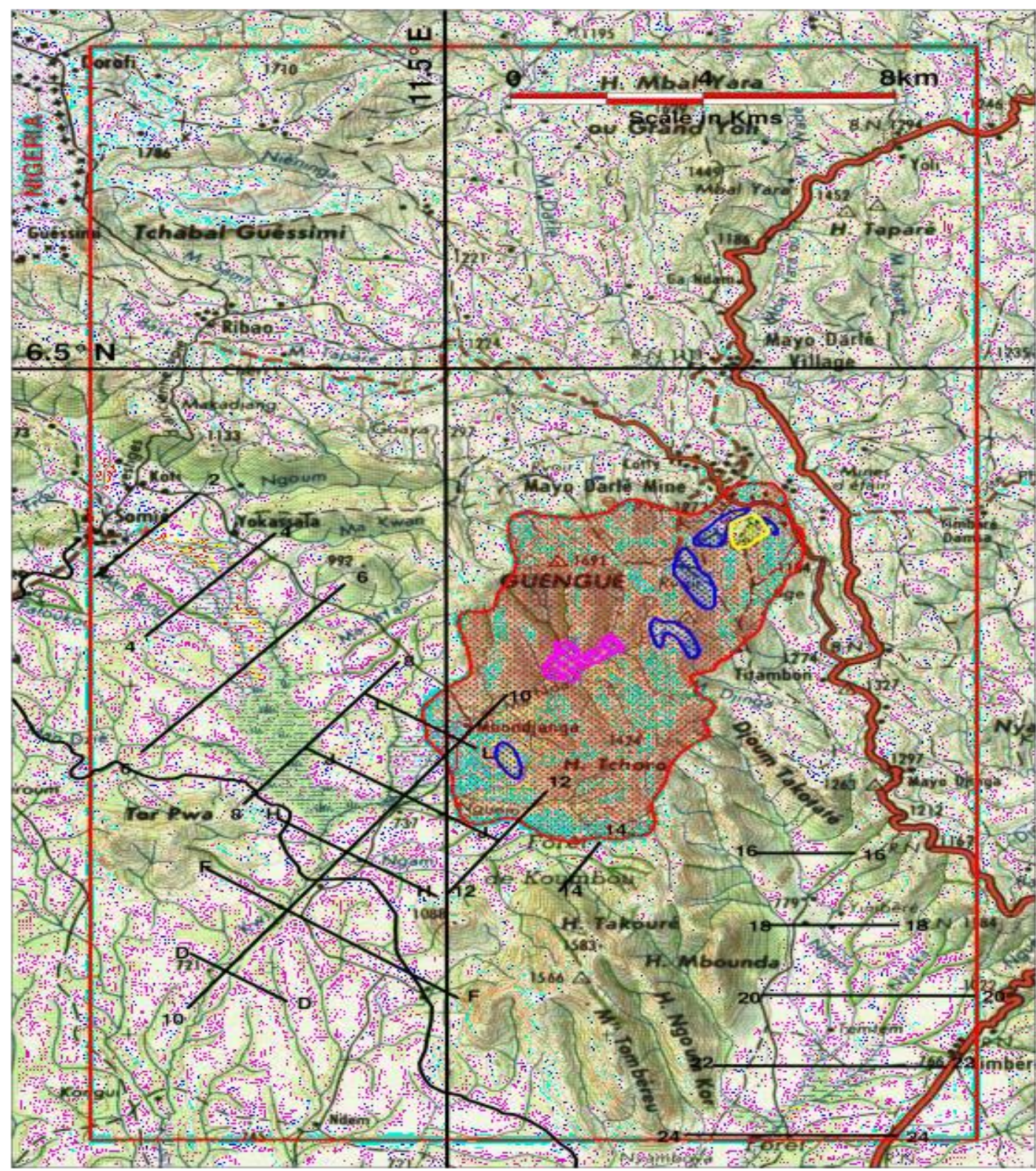

\section{Partial Legend :}

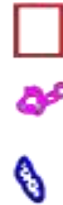

Permis Boundary

Hidden Valley

Known Griesen

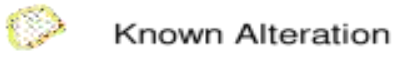

9 Guengue Granite

2/ $\mathbf{H}$ Drill Fence No.
SICAMINES sarl

Layout of Mayo Darle Southwest Alluvial Scout Drilling Programme

Figure 1: Layout of Mayo-Darlé Mine Exploration Site

Source: Field Survey, SICAMINES Sarl, 2007 
Assessing Green Policies for the Rehabilitation and Sustainable Restoration of Mine Sites in Cameroon: Case of the Mayo-Darlé Mine Site, Adamawa Region

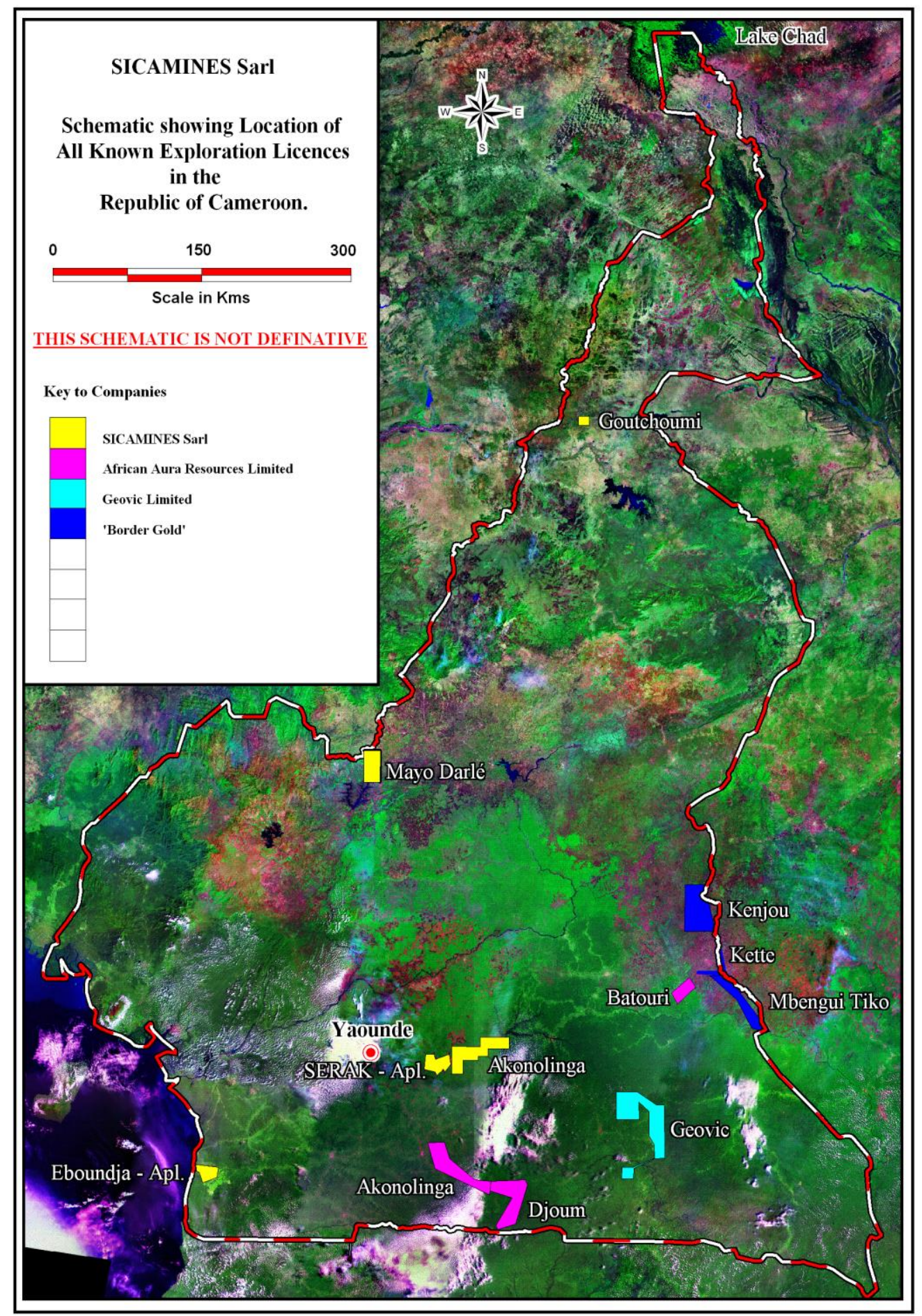

Figure 2: Satellite Image showing geo-location of Mine sites with exploration licence amongst wish Mayo Darlé Source: Field Survey, SICAMINES Sarl, 2007 


\section{Collection and Analysis of Field Data.}

This study required a grid of varied qualitative data. The methodology adopted is essentially based on three aspects of the theme namely: the green or environmental policies that govern the mining sector in Cameroon, the rehabilitation of the mine site, and the restoration of the environment. The data was collected through the review of some relevant literature obtained from institutional documents, scientific papers, semi-structured interviews with the support of a guide, and field observations (in situ) notably the nature of the trenches, ecological and socio-sanitary impacts of the post-exploitation of mine. The data collection operation also involved gathering the prescribed information from the selected observation units. Satellite imagery was used to geo-localize the MayoDarlé area on the Cameroon Map. Since the field data collected are globally qualitative, we opted, on one hand, to examine green policies established so far within the sector and the other to as sess their impacts socially, economically, and ecologically. Hence, the SWOT analysis (Strengths- Weaknesses - Opportunities-Treats) was used. Equally, a global hierarchy classification of potential risk over the long-term was presented.

\section{Results}

\section{Green and Mining Policies in Cameroon: An Overview of the Former Mayo-Darlé Mine}

\section{Presentation of an inventory offeatures in the Old Mayo-Darlé Mine}

The Mayo-Darlé mine was being exploited for a few decades before it was abandoned within 1990 1993. However, illegal artisanal exploitation and non-regulatory logging continued, increasing the risk of already existing land. The multiple trenches dug during extraction activities at the mine site were not covered and cleared after the activities. The presence of former unenclosed research drifts was also observed, which served as a relevant indicator of the rate of deterioration of the physical environment after mining activities. These operations required the cutting or burning of natural vegetation, the stripping of the soil to reach the tin ore (cassiterite) up to $25 \mathrm{~m}$ in the bedrock (BDMG Report, 2007). Here, we could observe the presence of bare soil, which was intensively exploited. As for the vegetation, it was mainly composed of small shrubs. In addition to this, there are holes and pits scattered around the mine, into which one can fall since they are covered with grass, as shown in the photos below. 


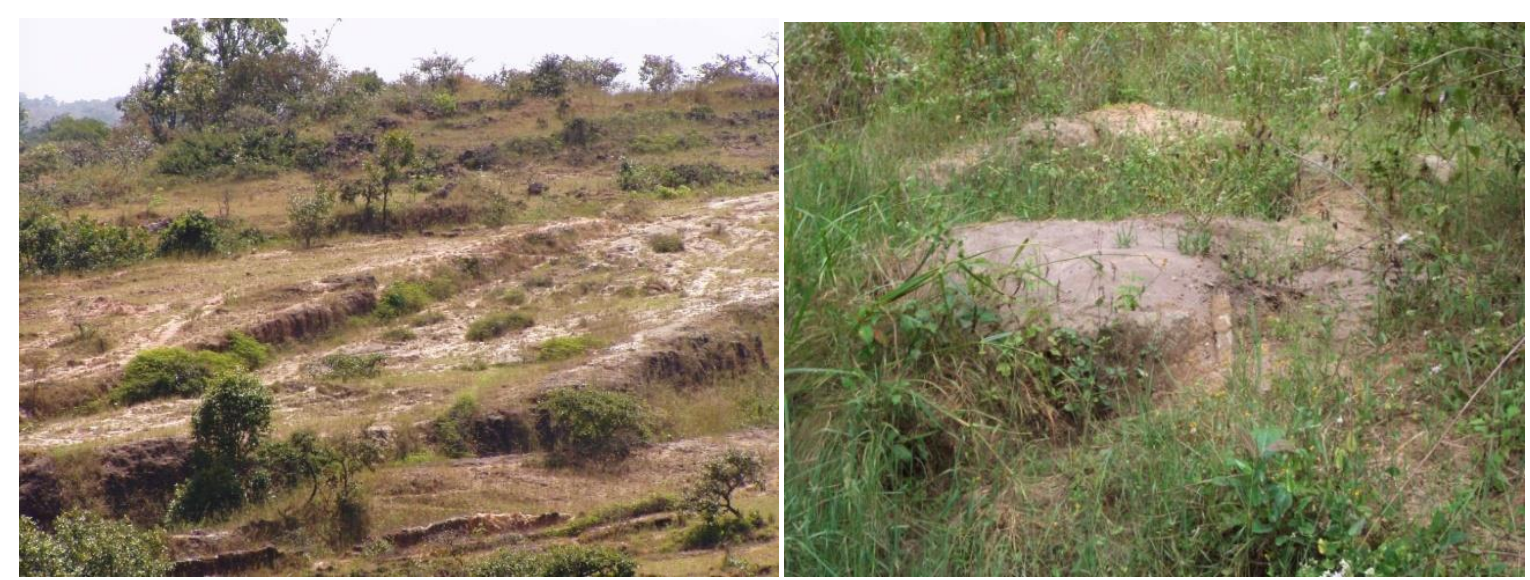

Pictures 1and 2: (1 Left) Trench remains; (2 Right) Holes and pits covered with grass Source: Field Geologist SICAMINES, 2017

On the other hand, a very intense alteration of rock (granite) that has rendered the soil material very fragile and unstable could be observed creating a favorable for a landslide to occur. Water erosion has also been noted since the colonial period (period of exploitation) and is not without negative consequences (ROOSE et al; 1973). Leaching causes mineralization in stream sediments; the surface waters thus often have more or less important concentrations of tin (Tn). The downstream area used by surrounding populations represents a major risk for the development of cancerous diseases and many others. More so, after mining operations, the landscape is left with huge, gaping pits, which disfigure the landscape.
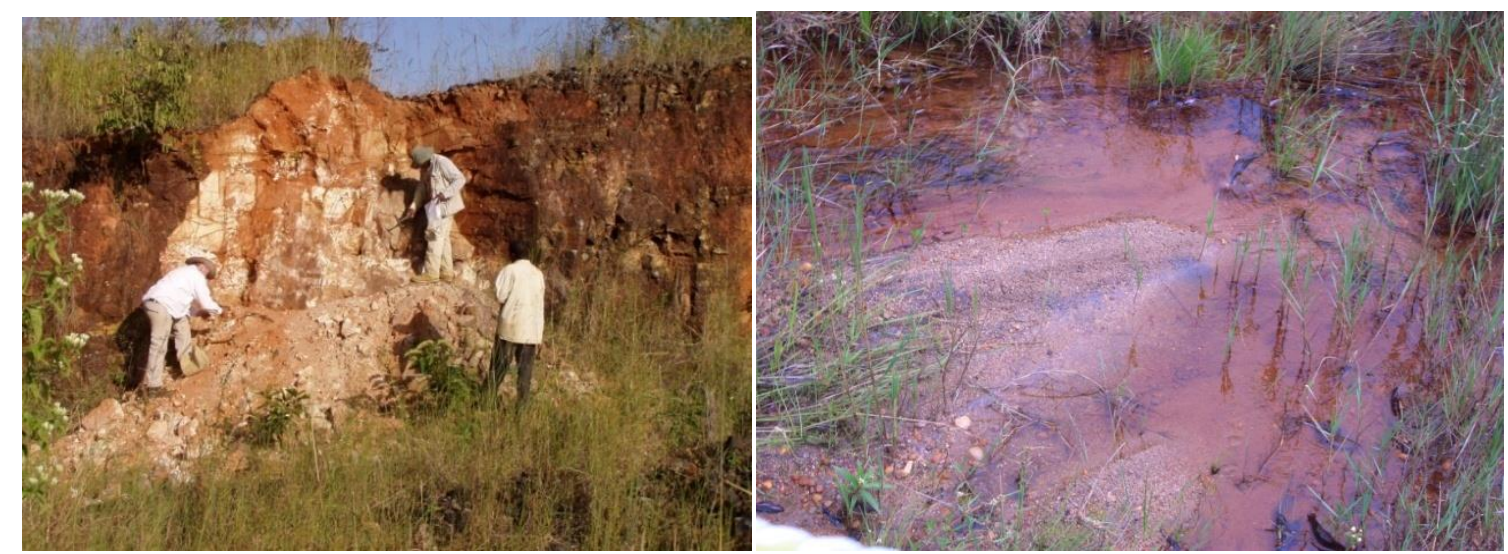

Pictures 3and 4: (3 Left) Partial soil alteration profile (4 left) Sediment deposits in a water course Source: Field survey, 2017 


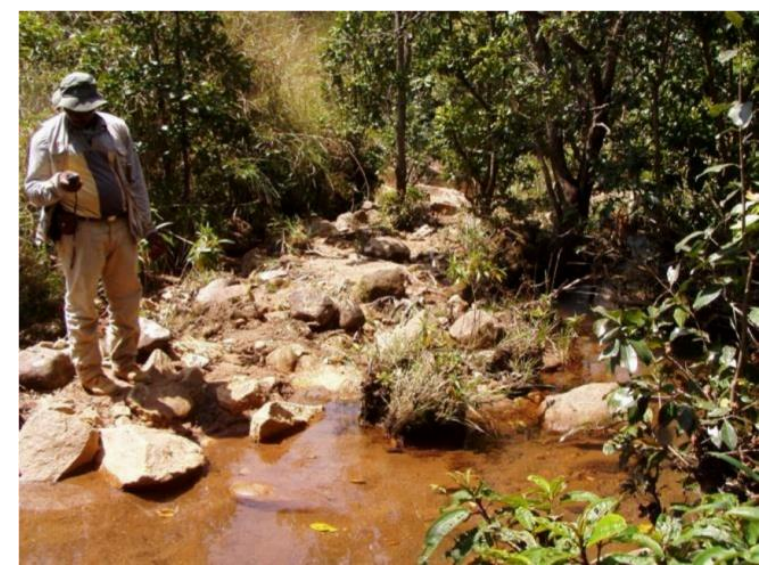

Picture 5: water source for multiple usages highly exposed to pollutants. Source: Field Survey 2017

Abel René Mahop, head of the Forestry Section at the Regional delegation of the Adamawa region, points out one of the difficulties involved in restoring the site. He specifies, "it often happens that local people refuse to allow the mines to be closed down; because they want to continue artisanal exploitation." However, abandoned mine site like that of Mayo Darlé remains crowded with people. Young people and adults of all ages are relentlessly digging and excavating around the huge crater left by the extracting company, creating in turn many other pits several meters deep. Meanwhile, women and children are sifting and washing the earth collected from the dirty crater rim to isolate the precious metal.

\section{Environmental Legislative Framework for the Management of Mine Sites in Cameroon.}

Established in August 1996 and instigated by the major recommendations of the Earth Summit in Rio, Cameroon came up with its relative framework and law for environmental management. In the course of its development, it defined the term environment as "all the natural or artificial elements and biogeochemical balances they participate in as well as the economic, social and cultural factors, which are conducive to the existence, transformation and development of the environment, living organisms and human activities" (Law No 96 / 12 of 5 August 1996. Relating to environmental management). Although complex, the above definition, very exhaustive ostensibly recognizes the symbiotic relationship between man and the environment and the interactions between the living and non-living matrixes. For a reminder, Article 5 of the said law stipulates that: laws and regulations must guarantee the right of everyone to a healthy environment and ensure a harmonious balance within ecosystems and between urban and rural areas. Based on this provision, we have the obligation to set up a sustainable management plan for our living spaces. The inclusion in article 9 of the 
Assessing Green Policies for the Rehabilitation and Sustainable Restoration of Mine Sites in Cameroon: Case of the Mayo-Darlé Mine Site, Adamawa Region

principles of precaution, preventive, and corrective action, the polluter-payer principle, that of subsidiary and responsibility highlights this vision of Cameroon to move towards sustainable management of its territory. This implies the involvement of each actor in the reinstatement of the changes imposed on ecosystems by man over space and time.

Environmental enforcement refers to the process of compelling obedience to environmental regulations. Putting together the global definition of environment and outlining the fact that the regulation has sanctioned and is strictly respected, relatively shows the vision given to the environmental code in Cameroon. The strict consideration of the provisions set out in Articles 17, 18, and 19 of the Environmental Code on the implementation of the Environmental Impact Assessment (EIA) lays important foundations in the development and management of mining sites before exploitation. Concerning the management of post-exploitation sites, Chapter 4 on the soil and subsoil protection act reminds us that: (1) Holders of mining titles or quarry titles are required on the obligation to restore the exploited sites. (2) However, holders of mining titles or quarry titles may choose to pay the financial cost of the refurbishment operations carried out by the competent Administration. The amount and the terms and conditions are reserved for the Fund provided for by this Act and may not be allocated otherwise (section 37). More so, the mining code prescribed in its article 135 paragraph 2 on the protection of the environment that except the authorizations of artisanal mining, the license of research, the authorization, exploitation for quarries craft for domestic usage must be granted a mining title and before exploitation. They should also be subjected to a Social and Environmental Impact Assessment as well as a danger and risk study.

Keubou (2019) stated "according to distribution in force since 2014, 25\% of taxes and value-added are intended to compensate the populations affected by this activity". The Ministry of the Environment is nevertheless optimistic on the new mining code, which guarantees a better involvement of the commune in mining activity. "Introducing the concept of an environmental impact notice, which must first be approved by the local councils; will take over where the old code was limited to an environmental impact study if approved by the central level in Yaoundé," says Marcel Wanie, an environmental officer working for the Division level of Ministry of the Environment.

Furthermore, a decree, dated July 2016, prohibits mining activities in the beds of rivers, their tributaries, and flood plains. The Ministry of Environment in Yaounde is well aware of these facts 
and their consequences. Marcel Wanie, deputy director in charge of environmental assessments, lists some of them.

Gap holes are traps for wildlife, domestic animals, and even humans. These holes are left where there used to be vegetation, which has been removed without reforestation measures, so the flora also suffers. They contribute to the disruption of certain watercourses, with risks of flooding of dwellings and plantations, in addition to the pollution of water resources and the destruction of aquatic fauna.

It is worthy of note that the mining code of Cameroon defines mining activity as being a reconnaissance, research, development, exploitation, processing, enrichment, transport, storage, loading, marketing, rehabilitation operation, and closure of mining sites. It is thus appropriate to say that the stage of rehabilitation is indispensable in understanding the life cycle of mining sites. The rehabilitation process would therefore, be regarded as the abandon of the former exploitation site in conditions of rural productivity, security, and visual appearance close to their original state in a sustainable manner and an acceptable and deemed appropriate manner recognized by the administration responsible for mining and the environment (Mining Code, 2016). According to Article 136 of the Code, the restoration, rehabilitation, and closure of quarry sites and mine is the responsibility of each operator to remove the plant from all facilities including the operating plant located on the site. The former mining and quarry site must find stable agro-sylvo pastoral productivity security conditions, visual aspects close to their original state or conducive to any new development in a sustainable manner and in a manner deemed appropriate and acceptable by the administration in charge of the mine of the environment and any other administration concerned.

As far as institutional actions are concerned to make the post-exploitation management of the sites sustainable, the Ministry of Water, Mines, and Energy has considered the creation of two technical structures in the implementation of sustainable national mining policy. These structures are the Mining Sector Development Fund (MSDF) and the Restoration, Rehabilitation and Closure of Mining Sites and Quarries Fund. The former shall finance mining inventory activities and detect anomalies and mining indexes as well as other development activities of the geological fracture. The latter shall be used to finance the implementation activities of the program of presentation and rehabilitation of the affected environment through the realization of Social and Environmental Impact Assessment for mining projects. 
Assessing Green Policies for the Rehabilitation and Sustainable Restoration of Mine Sites in Cameroon: Case of the Mayo-Darlé Mine Site, Adamawa Region

A SWOT analysis of green policies within the Cameroonian mining sector
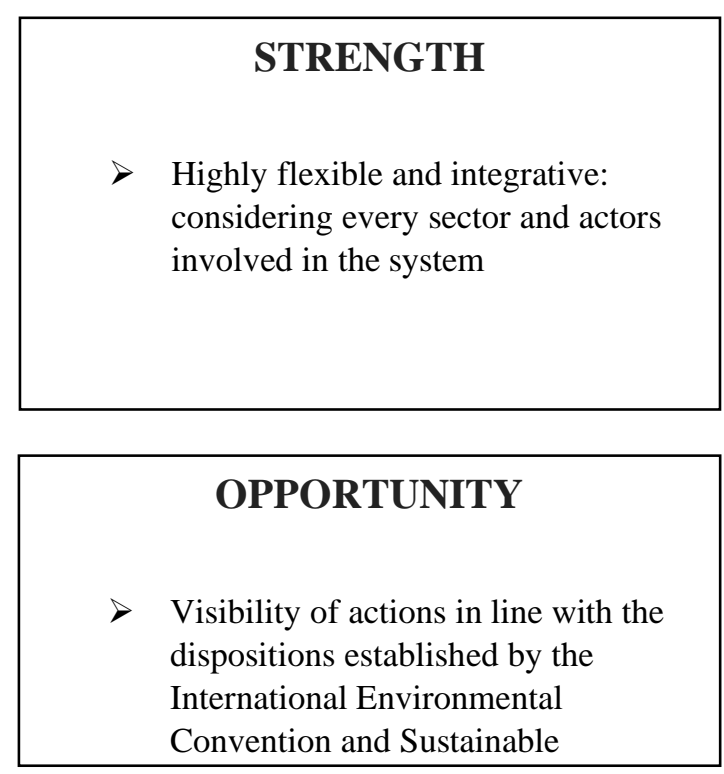

Source: Field survey, 2018

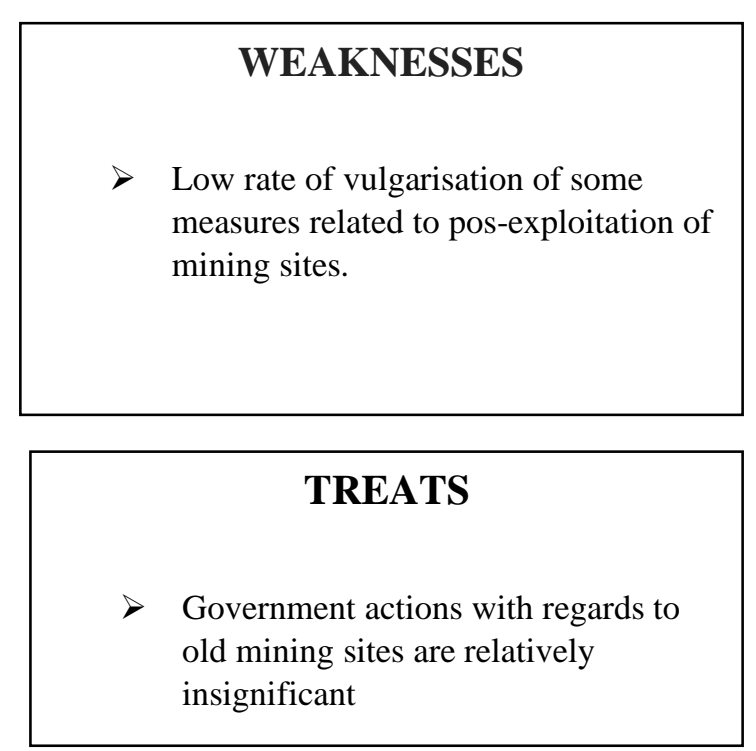

However, it is important to outline the fact that, obligations of restoration of the exploited site to its initial state though defined by law remain difficult in application. This is because of the nonavailability of the decree of application of the mining code yet to be established by the state. The decree of application will mention the percentage at which each mining operator will contribute (Mining site and Quarry Restoration, Rehabilitation and Closure Fund). Hence, despite this situation; operational structures in charge of the control of mining activities make sure that operators proceed at a progressive restoration.

Besides, due to the non-application of the decree, one could consider, as long-term effects, an intensive overlapping of the roles of actors in the mine control sector, which could lead to important management dysfunctions. According to (Nchunu; 2005), although Cameroon established its environmental legislation towards the end of the 20th century, green movements are still at their infant stage. This is the same for their implementation and application, which needs enforcement and compliance. The fragile state of the global environment, the rapid extinction of species, the threatening rate of environmental decimation, the intensive disruption of the ecosystem due to mineral overexploitation, and the lack of restoration facilities to support to small scale miners contribute drastically to this negative impacts witnessed here and there in mine sites in Cameroon. Hence, there is the need that actors should effectively enforce environmental criminal and management regulations 
and boost technical facilities for post-exploitation assistance where necessary to meet the exigencies of sustainable development.

\section{Socio-Economic and Environmental Impacts of Artisanal mining at the Mayo Darlé Old mine}

A cascade of environmental and social problems originate from the overlapping role of stakeholders in the mining governance system in Cameroon. Consequentially, we noticed that artisanal miners destroy fields, divert rivers, dig up the soil, and leave the site devastated. Hence, in the absence of the implementing decree sleeping on the Prime Minister's table, the law is difficult to apply (Chongwang, 2018). According to Aurélie Mokam and Cyrille Tsikam, researchers at the Geological and Mining Research Institute of Cameroon,

The impacts identified on health, the economy and the living environment, among others, are significant, with $82 \%$ negative impacts compared to $18 \%$ positive impacts.

Indeed, the environmental, social, and economic impacts of mining vary along with the different phases of a mining project. For example, activities associated with the exploration phase may require clearing wide areas of land and vegetation or the construction of a road that may have permanent effects on the livelihoods of local communities. Moreover, activities associated with placer mining exploitation - the mining of alluvial deposits for minerals such as gold or gemstones - may release large quantities of sediment that can impact surface water for several miles downstream of the placer mine generating social and environmental impacts for communities located far away from where the mining is taking place (IANRA,2016). Hence, to assess those risks many countries require companies to undertake EIAs and/or social impact assessments for the following reasons:

Refer to environmental audit and accompaniment programs;

Ensure water and solid waste management plans and plans for environmental rehabilitation at the end of operations;

Hold consultations with communities and share information on what has been done;

Contribute to an environmental fund and to assess state of mine sites 
Assessing Green Policies for the Rehabilitation and Sustainable Restoration of Mine Sites in Cameroon: Case of the Mayo-Darlé Mine Site, Adamawa Region

Extent, duration, probability, and significance of the identified potential environmental impact.

Practically, in Zimbabwe just like Cameroon, an EIA is required only before the commencement of mining. The post-assessment though instructed by law is to most cases not implemented. Globally, small-scale mining remains a challenge for sustainable local development. Artisanal mining at the Mayo-Darlé mine has both positive and negative impacts on the environment. Their socio-economic and ecological consequences turn to either boost local development or disrupt the economic cycle of the locality. From an economic point of view, mining has failed to stimulate local enterprises, traditional industries, and access to environmental resources. Mineral wealth continues to benefit the elite. According to Moyo Shoko and Mwitwa .J (2015) vulnerable and resources dependent communities bear the socio-economic and environmental costs of loss of access to land, impoverished livelihoods, and degraded environments. This situation is a similar picture of the context of the MayoDarlé mine site. Illegal and intensive mining from the colonial period to the early 2000 s has led to the depletion and a relative fall of tin mineral potential in this region hence accounting for a global economic loss of this resource. This has equally caused the cost of living very high in Mayo-Darlé especially during high extractive periods of the year. Socially, this archaic activity has led to a gross increase in population. This overpopulation phenomenon is caused by the high migration of miners from around the locality hence leading to insecurity and conflicts between small-scale mining associations. Equally, the intensive abuse of children of the Mayo Banyo division is an issue to take into consideration. This illegal labor is overtime becoming alarming and a measure treat for the community.

Furthermore, as far as the health sector is concerned, the intensive exploitation of tin and cobalt mineral exposes the population overtime turn to be very destructive diseases such as cancer and respiratory diseases not forgetting the prevalence of HIV/AIDS because of the high rate of unprotected sexual activities noted between the miners and women from the locality. Christelle Ngana Tankeu, a nurse at the Mayo Darlé Divisional medical center point out some of the most frequent health issues from activities in the mine site. "We have respiratory illnesses; because when digging the earth, they inhale dust, which causes diseases in their lungs. Then there are accidents due to landslides". From our exhaustive discussion with Kouankap Nono a leader of a local association, confirmed the fact water-borne diseases as well as sexually transmitted infections and diseases (STIs/STDs) are fuelled by promiscuity and poverty: "the women who are in these work sites are forced to give their body to have some food and money for their basic needs". However, there exists 
a positive impact. Though recognized as archaic and artisanal, mining in Mayo-Darlé is beneficial to the local community as it brings "life" and boosts small-scale commercial activities. Besides, the implantation of a medium-large scale mine in a "marginalized region" like the Adamawa with generally low school achievement will have a tremendous impact on the local population. Generally, there is no plan to prepare the local community to accommodate itself with the presence of the 'mine'. As a result, misinterpretations often occur with the artisanal miners over territory dispute, rights of way, utilization of water and local energy, etc. In the Ethiopian context, no procedures are in place to regulate, monitor or resolve conflicts between artisanal miners and exploration and mining companies (C2D Services Inc., 2013; Yihdego, 2018).

As for environmental consequences, we noticed a high rate of water, soil pollution. The PH value of the mayo-Darlé river is gradually increasing in acidity overtime due to an oxidation process on the combination of water and minerals. The consequences on human health are of prime importance as it leads to considerable sanitation and health damages (WHO, 2008). In the same way, their action renders the topsoil relatively fragile and tan thus accounts for considerable environmental risks and hazards like landslide (Earthwork, 2015). To find a way out of the negative pictures attributed to artisanal and Small-scale mining, critical ecosystems and vulnerable groups are some of the fields that should be given particular attention. Some measures taken at this level are the identification of potential solutions and alternative approaches through assessment of past efforts (both successes and failures) to address the identified short- and long-term environmental impacts (Obiri. S, Mattah $\mathrm{P}$, et $a l ;$ 2016). In the same way, it is important to identify and develop measures that can produce concrete improvements in critical ecosystems through sustainable solutions that reduce the environmental and social damage caused by artisanal small-scale mining, while building on its economic, social, and empowerment potential.

\section{Understanding the rehabilitation and restoration Concept}

Restoration and rehabilitation of mine is still a relatively new science. It is informed by the new discipline of restoration ecology. Land restoration occurs at a range of different scales. Mine rehabilitation has developed many successful practices of land restoration at a site-specific scale. The challenge ahead is to develop effective land restoration practices at a regional or landscape scale (Bell, 2002). Most success at both scales has since hitherto been concerned with restoring key ecosystem functions like nutrient cycling and water balance. Indeed, ecological restoration is the process of 
Assessing Green Policies for the Rehabilitation and Sustainable Restoration of Mine Sites in Cameroon: Case of the Mayo-Darlé Mine Site, Adamawa Region

repairing these affected ecosystems, with the main goal of bringing them back to some level of health, integrity, and self-sustainability. If the size of the impact is small and manageable, all that may be needed is a gentle prod to shift the ecosystem back (passive restoration) towards its natural state. This is the case of Mayo-Darlé. But if this does not happen within a reasonable time frame, active measures might need to be put in place (active restoration), such as the reintroduction of important species. The latter shows a critical situation yet to be examined over time.

However, rehabilitation typically occurs on post-mining sites and sites heavily affected by overgrazing leading to extensive soil depletion. If ecosystems are so badly damaged that they can no longer recover, even with the best of efforts, they are usually reassigned to a different function (reallocation). In South Africa, mine closure liability and rehabilitation system have come under increased scrutiny following recent events, namely, the acid mine drainage crisis, several judgments on post-closure liability (Harmony Gold, 2005); (Stilfontein Gold Mining, 2006); (Kebblev, 2007); Harmony Gold 2012); (Harmony Gold, 2014) (MPRDA Amendment Bill, 2013). Attention has, in particular, been focused on the financial provision, the duration of liability, and the gaps which allow companies to contract out of their mine closure obligations (WWF, 2012), (Humby, 2013). Public interest organizations have also raised issues such as how mining companies rehabilitate the environment, not forgetting whether the language in which the Mineral and Petroleum Resources Development Act (MPRDA) couches the conditions triggering the closure certificate process allows mines to avoid these obligations.

Planning the restoration of mine site like that of Mayo-Darlé requires considering the goals, objectives and the criteria to be given to space in a systematic manner whiling giving the possibilities for eventual modifications overtime. The restoration concept in developing countries through gradually appreciated and considered my local government is still more experimental (Cooke; Johnson, 2002). Its opportunity and credits come from its flexibility, as it could be adapted to different contexts and mining history of a geological site. Thus, associating a keen follow-up of the process is of necessity as monitoring the transformation of land could enable introducing new changes that most often ties to technological evolution over space and time. 


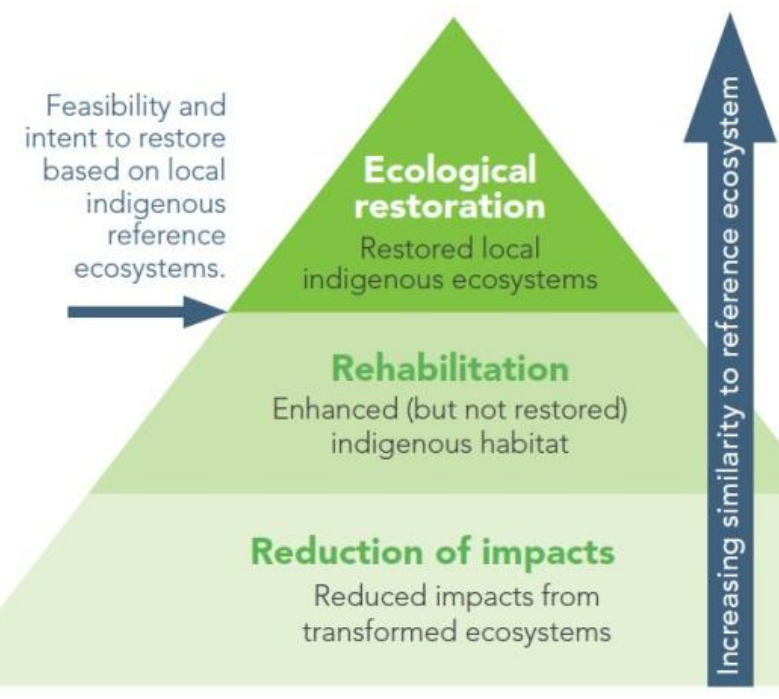

\section{Discussion}

\section{Perspective: An Eco-Sustainable Strategy for the Mayo-Darlé Old Mine}

Source: National standards for the practice of ecological restoration in Australia Second edition - June 2017

The establishment of a green network to encourage artisanal sustainable practices within mining fields could be the beginning of a new era. The harmonization and development of comprehensive policies and plans for mining zone management including production, conservation, restoration, and rehabilitation practices should be regarded as the key to the sustainable development and livelihood of the Mayo-Darlé community and its neighboring societies. Considering the recognition and safeguarding of the rights of local communities to access and share benefits for their livelihoods (Pollisco, 2014), the population of Mayo Darlé should be allowed to benefit from the exploitation of some important resources such as Tin and Cobalt in their locality. These could help the rural council to build water points and schools, which are basic services that could contribute to the development of this area. Furthermore, ensuring the integration of grassland and savanna ecosystem management and restoration for Disaster Risk Reduction and Climate Change Adaptation are some other measures that could give credits to the proposed strategy. Alongside the proposed measures above, the establishment of major infrastructures such as the creation of an Eco-touristic center, cultural and botanic parks, and their establishment of vegetation cover on mine grounds such as tree planting campaigns are to some extent the aspects to be integrated into Mayo-Darlé. Sustainability in the mining sector has multiple dimensions. A single approach to achieving mining sustainability is will 
Assessing Green Policies for the Rehabilitation and Sustainable Restoration of Mine Sites in Cameroon: Case of the Mayo-Darlé Mine Site, Adamawa Region

not be a good choice for developing countries (Yihdego and Salem, 2017). Instead, the perspectives of multiple stakeholders, including industry personnel, politicians, and environmentalists, need to be considered. Achieving sustainable development in mining and minerals seeks to offer a critical examination of many different perspectives, as well as disciplinary approaches to sustainable development in the mining and mineral sectors. Efforts need to be made to contribute to different themes of mining and minerals sustainability such as community, operational challenges and opportunities, environment, finance and case studies, and models and frameworks (Yihdego et al; 2018). Therefore as mentioned by Nöffke (2014), the correct application of soil conservation and biodiversity principles and techniques remains fundamental to our survival. This assertion is in line with the recommendation of Ametissa Zabagai (2018), Environmental Delegate for the Adamawa region who said, "It is our responsibility to preserve and protect the environment in which we live especially Darlé where artisanal mine exploitation has been constant these past years".

Moreover, for technical assistance in the artisanal mining sector, the state of Cameroon created the (full meaning should precede the ACRONYM) CAPAM, which is a framework for the support and promotion of the mining craft Industries. By the decree $\mathrm{N}^{\circ} 064 / \mathrm{PM}$ of 25 July 2003. This institution has as societal responsibility, the intimate conciliation between the economic profitability of a company, social, environmental, and good governance concerns. Within this framework, CAPAM is of prime importance because its activities are centered on the social and environmental concerns caused by artisanal mining (CIMEC, 2013). Practically, they provides artisanal miners at the level of each Mining Brigade with Mining Engineers, Mining Geologists, and Management Executives who support them in the following areas: -mining prospecting techniques; - artisanal mining techniques; processing, concentrating and marketing of mining products; - environmental rehabilitation techniques, etc. Concerning the environmental protection of mine sites, like that of the Mayo Darlé, CAPAM organized in 2005 and 2009 two important national training and support programs for artisanal miners on the restoration of mine sites. Here specific attention where given to the legal aspects of environmental matters relating to artisanal mining activity; the current state of the environmental situation in artisanal mining sites in general; proposed solutions for compliance with environmental standards in force; and the development of standard specifications for the preservation of the environment to artisanal mining activity (CAPAM, 2018). Although mush still have to be done at this level, the State of Cameroon is gradually focused towards the amelioration of artisanal mining by considering the restoration of sites a central element in the sustainability of its mining sector, to the light of countries like Ghana and South Africa. 


\section{Conclusion}

According to Richard W. Bell (2002), land degradation caused by mining is closely regulated and mining companies have contractual requirements with Governments to restore mined land to an agreed standard. However, this step is common in every mining exploration system worldwide, notably for developed countries, African states yet need to reduce the gap in policy implementation within this sector. The Mayo-Darlé case in Cameroon shows a true picture of the African reality. Indeed, the mining sector has become a battlefield where government measures are in constant conflicts with private actors concerning mine site management. Hence, this study is in line with sustainable development goals. It addresses the place of Eco-Sustainable Strategies to rethink the development of abandoned mine sites. Through concepts like rehabilitation and restoration outlined throughout the work, this study could therefore stand not only as an experimental case for mining site management in Cameroon but also as an instigator of sustainable practices for our mining environment.

\section{References}

Ali Somarin (2014). Mining and the Environment: What Happens When A Mine Closes? Thermo Fisher Scientifics.

Bell. W.R, (2002) Restoration of Degraded Landscapes: Principles and Lessons from Case Studies with Salt-affected Land and my Revegetation, CMU. Journal (2002) Vol. 1(1)

Bell, F.; Genske, .D. (2000). Restoration of derelict mining sites and mineral workings', bulletin of engineering geology and the environment, vol. 59, pp. 173-185

Benno Pokorny, Christian von Lübke, Sidzabda Djibril Dayamba, Helga Dickow, (2019). All the gold for nothing? Impacts of mining on rural livelihoods in Northern Burkina Faso, World Development, Volume 119,Pages 23-39,ISSN 0305-750X.

BRGM (2009). Proposed decrees and orders necessary taking into account the existing situation in mines and the evolution of international mining environmental standards, p19.

Cameroon Mining Code: Law n²016-17 of December 14, 2016

C2D Services Inc. (2013). Education for Mining Development Study Background Study, To Canadian International Development Agency (CIDA) Gatineau, Quebec, Canada Mission report, 28 June 28.

Chongwang .J, (2018). Cameroon: Mines in the East, a Threat to the Environment. Field Report.

Chastel.D; Godzinski.F. (1994). Réhabilitation de sites miniers: Exemple du Grand ' Baume, forêt méditerranéenne t. xv, $\mathrm{n}^{\circ}$ 3, juillet 1994

Cobârzan. B (2008). Environmental rehabilitation of closed mines: a case study on Romania, Transylvanian review of administrative sciences, 22e/2008 pp. 34-43 
Assessing Green Policies for the Rehabilitation and Sustainable Restoration of Mine Sites in Cameroon: Case of the Mayo-Darlé Mine Site, Adamawa Region

Cooke. J, Johnson. M, (2002). Ecological restoration of land with particular reference to the mining of metals and industrial minerals: A review of theory and practice, Dossiers Environment, 2002, 10(1): 41-71, https://doi.org/10.1139/a01-014

Filiberto Pollisco, JR. (2014). Mangroves \& Mined Out Areas Rehabilitation/Restoration in Southeast Asia and Their Implication to Designing ECR Projects, communication in the "Capacity Building for Central, South and East Asia on Ecosystem Conservation and Restoration to Support Achievement of the Aichi Biodiversity Targets",14 - 18 July 2014, Jeju, South Korea.

Funoh. K. (2018). The impacts of artisanal gold mining on local livelihoods and the environment in the forested areas of Cameroon, Working Paper, CIFOR.

Guide de Préparation du Plan De Réaménagement et de Restauration des Sites Miniers Au Québec, 2017

International Alliance of Natural Ressource in Africa (IANRA).(2016). African Mining and Mineral Policy Guide: A resource for nongovernmental organizations, activists, communities, governments and academics

Kebblev Minister of Water Affairs (2007) JDR 0872 (SCA).

Kristina Söderholm, Patrik Söderholm, Heidi Helenius, Maria Pettersson, Roine Viklund, Vladimir Masloboev, Tatiana Mingaleva, Viktor Petrov. (2015).Environmental regulation and competitiveness in the mining industry: Permitting processes with special focus on Finland, Sweden and Russia, Resources Policy, Volume 43, Pages 130-142, ISSN 0301-4207. https://doi.org/10.1016/j.resourpol.2014.11.008.

Laroche. O, (2011) Revégétalisation des sites miniers et valorisation de boues de stations d'épuration : cas de la Nouvelle-Calédonie, Essai présenté au Centre Universitaire de Formation en Environnement en vue de l'obtention du grade de maître en environnement (M.Env.), Centre Universitaire de Formation En Environnement Université De Sherbrooke,Québec, Canada.

Loi $n^{\circ}$ 96/12 du 5 aout 1996 portant loi-cadre relative a la gestion de l'environnement 96

Mayo-Darlé Municipal Development Plan, 2014

Ministry of Mines, Industry and Technological Development, (2013) CIMEC- International Mining Exhibition \& Conference In Cameroon, Social Responsibility In Artisanal Mining In Cameroon: The Case of CAPAM.

Mwitwa .J, (2015), Socio-economic impact of small-scale emerald mining on local community livelihoods: the Case of Lufwanyama District, International Journal of Education and Research Vol. 3 No. pp375- 389

Nchunu. J (2003). Sustainable use of forest and wildlife resources in central Africa: key policy challenges, 2nd pas IUCN at 217 or www.iucn.org/bookstore

Nchunu .J (2005) criminal law and environment, prosecutors, inspectors and NGOs in Cameroon, www.iucn.org/bookstore

National Plan for Environmental Management, General Report, 8 November 2016.

Obiri. S, Mattah P, et al, (2016) Assessing the Environmental and Socio-Economic Impacts of Artisanal Gold Mining on the Livelihoods of Communities in the Tarkwa Nsuaem Municipality in Ghana, International Journal of Environmental Research and Public Health,13, 160; DOI:10.3390/ijerph13020160

Pawanezambo Ilboudo. S (2012), la réhabilitation des sites miniers comme une alternative de restauration de l'environnement : cas de la mine d'or de morila au mali, mémoire pour l'obtention du master spécialisé en gestion durable des mine, 2 ie.

"Recent Advances in Environmental Science from the Euro-Mediterranean and Surrounding Regions", Springer Nature, 2018 
Roley Nöffke, (2014). Mine and Associated Rehabilitation Projects in Africa and the Indian Ocean Islands, a conference organized by Vetiver Network International; Region2-Southern Africa Chapter and Hydromulch Ltd, Johannesburg, Republic of South Africa

Söderholm. P et al (2015), mining and sustainable development: Environmental regulation and mining sector competitiveness

Ucilia Wang (2015) Sustainable mining: an inherent contradiction in terms? The Guardian.

Villeneuve. C, Riffon. O, Segers. I, Tremblay. D (2015). Les défis du développement durable dans l'industrie minière, Dans: Mines et Développement Durable, comment aborder la quadrature ducercle ? L'industrie minière et le développement durable -Une perspective internationale francophone.

Yohannes Yihdego; Hilmi S. Salem; Benard Ayongaba; Zarko Veljkovic (2018), Mining sector challenges in developing countries, Tigray, Ethiopia, and inspirational success stories from Australia, International Journal of Mining and Mineral Engineering, Vol. 9, No. 4, 201832. 